\title{
Purification and characterization of the kinetic parameters of cellulase produced from wheat straw by Trichoderma viride under SSF and its detergent compatibility
}

\author{
Hafiz Muhammad Nasir Iqbal ${ }^{*}$, Ishtiaq Ahmed ${ }^{1,2}$, Muhammad Anjum Zia ${ }^{1}$, Muhammad Irfan ${ }^{2}$ \\ ${ }^{1}$ Enzyme Biotechnology Laboratory, Department of Chemistry and Biochemistry, University of Agriculture, Faisalabad, Pakistan; \\ ${ }^{2}$ Food Biotechnology Research Centre, Pakistan Council of Scientific and Industrial Research Labs, Lahore, Pakistan. \\ Email: nasir_pk99@hotmail.com
}

Received 16 January 2011; revised 15 February 2011; accepted 17 February 2011.

\section{ABSTRACT}

This paper reports the purification and characterization of kinetic parameters of cellulase produced from Trichoderma viride under still culture solid state fermentation technique using cheap and an easily available agricultural waste material, wheat straw as growth supported substrate. Trichoderma viride was cultured in fermentation medium of wheat straw under some previously optimized growth conditions and maximum activity of $398 \pm 2.43 \mathrm{U} / \mathrm{mL}$ obtained after stipulated fermentation time period. Cellulase was purified 2.33 fold with specific activity of $105 \mathrm{U} / \mathrm{mg}$ in comparison to crude enzyme extract using ammonium sulfate precipitation, dialysis and Sephadex-G100 column chromatography. The enzyme was shown to have a relative low molecular weight of $58 \mathrm{kDa}$ by sodium dodecyl sulphate poly-acrylamide gel electrophoresis. The purified enzyme displayed 6.5 and $55^{\circ} \mathrm{C}$ as an optimum $\mathrm{pH}$ and temperature respectively. Using carboxymethyl cellulose as substrate, the enzyme showed maximum activity $\left(V_{\max }\right)$ of $148 \mathrm{U} / \mathrm{mL}$ with its corresponding $K_{\mathrm{M}}$ value of $68 \mu \mathrm{M}$. Among activators/inhibitors SDS, EDTA, and $\mathbf{H g}^{2+}$ showed inhibitory effect on purified cellulase whereas, the enzyme activated by $\mathrm{Co}^{2+}$ and $\mathrm{Mn}^{2+}$ at a concentration of $1 \mathrm{mM}$. The purified cellulase was compatible with four local detergent brands with up to 20 days of shelf life at room temperature suggesting its potential as a detergent additive for improved washing therefore, it is concluded that it may be potentially useful for industrial purposes especially for detergent and laundry industry.

Keywords: Cellulase; Trichoderma Viride; Purification; SDS-PAGE; Characterization; Detergent Compatibility

\section{INTRODUCTION}

Cellulase is a generic name for the group of enzymes which catalyze the hydrolysis of cellulose and related cellu-oligosaccharide derivatives. Cellulose consists mainly of long polymers of $\beta 1-4$, linked glucose units and forms a crystalline structure [1]. The cellulase complex is comprised of three major components: Carboxymethyl cellualase (CMCases) or Endo-ß-glucanase (EC 3.2.1.4), Exo-ß-glucanase (EC 3.2.1.91) and $\beta$-glucosidase (EC 3.2.1.21) [2,3]. Cellulases from various sources have distinctive features as they exhibit specific $\mathrm{pH}$ optima, solubility depending on the amino acid composition. Thermal stability and exact substrate specificity may also vary with the origin $[4,5]$.

The major bottle neck against comprehensive application of cellulases in industry is the high cost of the enzyme production. Currently, most commercial cellulases (including $\beta$-glucosidase) are produced by Trichoderma species and Aspergillus species [6]. Cellulases are used widely: in the textile industry for cotton softening and denim finishing; in the detergent market for color care, cleaning, and anti-deposition; in the food industry for mashing and in the pulp and paper industries for deinking, drainage improvement, and fiber modification [6, 7].

Solid state fermentation (SSF) is a process that occurs in the absence of free flowing water and an attractive method to produce cellulase from micro-organisms [810], which is economical due to its lower capital investment, lower operating expenses, simpler equipment and higher productivity per reactor volume [11-13]. Cellulose and hemicellulose represent the largest fraction of the plant cell wall and of agricultural residues such as straw from wheat, corn, rice, soy and cotton, sugarcane bagasse, bonds with the lignin in the cell wall matrix need to be broken. For this reason, the direct feeding 
fiber has not yielded the expected favorable results considering the nutritional and energetic potential of these fibers [14].

Many filamentous fungi produce cellulases to perform cellulolysis necessary for growth and product formation under appropriate conditions. Commercial cellulase preparations from most often used species Trichoderma ressei and Trichoderma viride are popular as it contains high activities of both exo-glucanase and endo-glucanase but low levels of $\beta$-glucosidase [13]. In this present study, the properties of purified cellulase produced from Trichoderma viride using wheat straw as growth supported substrate; which is cheaper and easily available energy source were investigated. Our data suggest that the organism produce cellulase which differed in its molecular weight significantly from other Trichoderma sp and compatible with locally available detergent brands having optimum shelf life of up to 20 days at room temperature, suggesting its potential for biotechnological applications.

\section{MATERIALS AND METHODS}

\subsection{Chemicals and Substrate}

All the chemicals used in this study were of analytical grade and purchased from Fluka (France), Merk (Germany) and Sigma Chemical Co., USA. An agricultural waste wheat straw was used as solid substrate and obtained from Student research Farms, University of Agriculture, Faisalabad (UAF), Pakistan. The substrate was oven dried $\left(60^{\circ} \mathrm{C}\right)$, ground to fine particle size and stored in air tight plastic jars to keep it moisture free.

\subsection{Micro-Organism, Maintenance and Inoculum Development}

The pure culture of Trichoderma viride available in the Enzyme Biotechnology Laboratory; Department of Chemistry and Biochemistry, University of Agriculture Faisalabad, was used as cellulase enzyme producer. Spores of Trichoderma viride were grown and maintained on Potato Dextrose Agar (PDA) slants. Spores of Trichoderma viride from PDA slant were cultivated in an Erlenmeyer flask (250 mL) containing $30 \mathrm{~mL}$ of Potato Dextrose broth at $30 \pm 1^{\circ} \mathrm{C}$ for 7 days after sterilizing the broth at $15 \mathrm{lbs} /$ inch $^{2}$ pressure and $121^{\circ} \mathrm{C}$ in laboratory scale autoclave (Sanyo, Japan) for 15 minutes, $\mathrm{pH}$ was adjusted before sterilization, and incubated under stationary conditions for the development of fungal spore suspension [15].

\subsection{Production and Extraction of Cellulase}

Cellulase from Trichoderma viride was produced under pre-optimized growth conditions [16]. To achieve maximum cellulase activity proximally analyzed agricultural waste material, wheat straw was inoculated at $45^{\circ} \mathrm{C}$ after pretreatment with $2 \% \mathrm{HCl}, 3 \%$ substrate concentration $40 \%$ moisture content with optimum pH 5.5 and 10\% inoculum's size. After stipulated fermentation time period, cellulase was extracted from the fermented biomass by adding distilled water as extraction solvent in 1:10 $(\mathrm{w} / \mathrm{v})$ ratio and the flasks were shaken at $120 \mathrm{rpm}$ for 30 minutes [16]. The contents were filtered through muslin cloth and washed thrice with distilled water. The filtrates were centrifuged at $10,000 \times \mathrm{g}\left(4^{\circ} \mathrm{C}\right)$ for 10 minutes and carefully collected supernatants were used for enzyme activity determinations and also used for purification purposes.

\subsection{Determination of Enzyme Activity and Protein Concentration}

Enzyme activity of supernatants was determined using spectrophotometry (T60, PG Instruments, UK) by the method of Ghose, [17]. The reaction mixture contained $0.5 \mathrm{~mL}$ of carboxymethyl cellulose as substrate in $0.05 \mathrm{M}$ $\mathrm{Na}$-citrate buffer of $\mathrm{pH} 4.8$ and finally $0.5 \mathrm{~mL}$ of diluted crude enzyme and incubated at $50^{\circ} \mathrm{C}$ for $30 \mathrm{~min}$. An appropriate control which contained $0.5 \mathrm{~mL}$ of distal water instead of crude enzyme extract was also run along with the test. At the end of the incubation period, tubes were removed from the water bath, and the reaction was stopped by addition of $3 \mathrm{~mL}$ of 3, 5-dinitrosalicylic acid reagent per tube. The tubes were incubated for $5 \mathrm{~min}$ in a boiling water bath for color development and were cooled rapidly. The activity of reaction mixture was measured against a reagent blank at $540 \mathrm{~nm}$. The concentration of glucose released by enzyme was determined by comparing against a standard curve constructed similarly with known concentrations of glucose. The recorded activities were expressed as $\mathrm{U} / \mathrm{mL}$ while, unit activity was defined as the amount of enzyme required to produce a unit increase in absorbance at specific wavelength $(\mathrm{nm})$ per $\mathrm{mL}$ of reaction mixture. The protein concentrations in crude and purified enzyme extracts were determined by the method of Lowry et al. [18], using bovine serum albumin as standard.

\subsection{Partial Purification Procedure}

The method of De-Moraes et al. [19] with minor modifications was followed for purification of cellulase (CMCase). Crude extract obtained from Trichoderma viride was centrifuged $10,000 \times \mathrm{g}$ for 15 minutes at $4^{\circ} \mathrm{C}$ to increase clarity. After obtaining clarity to maximum level, solid crystals of ammonium sulfate were added to the crude enzyme extract until it was 50\% saturated and kept for 4 - 6 hours at $4^{\circ} \mathrm{C}$. The resulting precipitate was collected by centrifugation at $10,000 \times \mathrm{g}$ for $15 \mathrm{~min}$ at $4^{\circ} \mathrm{C}$. The pellets of precipitated proteins were discarded 
and in the supernatant, more crystals of ammonium sulfate were added to attain $85 \%$ saturation at $0^{\circ} \mathrm{C}$. It was again kept for $4-6 \mathrm{~h}$ at $4^{\circ} \mathrm{C}$ and centrifuged as described previously. After centrifugation the supernatant was kept separate and sediments were dissolved in small amount of $0.2 \mathrm{M}$ Tris-HCl buffer ( $\mathrm{pH}$ 8). The solution was kept in a dialysis bag and after sealing securely, dialyzed against distilled water with 4 regular changes of the water after every $6 \mathrm{~h}$. Total proteins and activity of partially purified cellulase were determined before and after dialysis of ammonium sulfate precipitation as mentioned before. The partially purified cellulase was lyophilized and used for further studies related to gel filtration chromatography and SDS-PAGE for further purification and molecular weight determination respectively.

\subsection{Gel Filtration Chromatography}

Partially purified cellulase was subjected to gel filtration chromatography using Sephadex-G-100 (Sigma, USA) column for further purification. The column was packed to the height of $120 \mathrm{~cm}$ in a glass column with an internal diameter of $2.0 \mathrm{~cm}$ [20]. The sample was poured on top of the column and eluted with phosphate buffer of $\mathrm{pH}$ 6.5. The flow rate was maintained at $0.5 \mathrm{~mL} \cdot \mathrm{min}^{-1}$. Up to 20 fractions were collected each of $1 \mathrm{~mL}$ and both the enzyme activity and protein content were determined for each separate fraction, as mentioned in the previous section.

\subsection{SDS-PAGE for Molecular Weight Determination}

Sodium dodecyl sulphate poly acrylamide gel electrophoresis (SDS-PAGE) was performed on a 5\% stacking and a $12 \%$ separating gel according to the method of Laemmli [21] to determine the molecular weight of purified cellulase. To $100 \mu \mathrm{L}$ of protein sample, $50 \mu \mathrm{L}$ of sample buffer $(0.05 \%$ bromophenol blue, $5 \% \beta$-mercaptoethanol, $10 \%$ glycerol, and 1\% SDS in 0.25 M Tris$\mathrm{HCl}$ buffer; $\mathrm{pH}$ 6.8) was added and boiled in boiling water bath for $5 \mathrm{~min}$, cooled at room temperature and loaded onto the gel. Electrophoresis was performed at room temperature for $2.5 \mathrm{~h}$ with a 120 Volt and then gel was placed in fixing solution for 20 minutes followed by washing with three changes of distal water over 30 minutes time period. The protein bands were visualized by staining with Coomassie Brilliant Blue G (Sigma) and destaining was done again with distal water and kept for overnight in water at room temperature. The molecular weight of the purified cellulase was determined in comparison to marker protein (standard protein marker, 21116 kDa; Sigma, USA) after documentation.

\subsection{Characterization of Purified Cellulase}

The purified cellulase was subjected to characterization through kinetic studies by studying the effect of different $\mathrm{pH}$ values (4 - 10), different incubation temperatures (30 - $\left.60^{\circ} \mathrm{C}\right)$, varying concentrations $(100-1000 \mu \mathrm{M})$ of carboxymethyl cellulose as substrate and various compounds and metal ions (SDS, EDTA, $\mathrm{Hg}^{2+}, \mathrm{Co}^{2+}$ and $\mathrm{Mn}^{2+}$ ) as activators and inhibitors on purified cellulase produced from Trichoderma viride was studied with $1 \mathrm{mM}$ of concentration.

\subsection{Industrial Application}

\subsubsection{Detergent Compatibility of Cellulase}

Four locally available detergent brands (Surf excel, Ariel Wheel and Bright Total) were used for studying compatibility of purified carboxymethyl cellulase under normal conditions. Detergent solutions were prepared as per directions given on their respective sache. Carboxymethyl cellulose solution (1\%) was used as substrate and prepared in phosphate buffer of $\mathrm{pH}$ 6. A reaction mixture comprising $3 \mathrm{~mL}$ of substrate solution, $1.1 \mathrm{~mL}$, detergent solution and $0.9 \mathrm{~mL}$, purified cellulase was incubated at $55^{\circ} \mathrm{C}$ for 10 - 15 minutes followed by normal enzyme assay as described earlier. A control sample was also incubated in parallel to reaction mixture solution.

\subsubsection{Shelf Life of Purified Cellulase}

Shelf life or storage is an important parameter for commercial utilization of industrial products. The purified cellulase stored at room temperature $\left(30^{\circ} \mathrm{C}\right)$ for $20-30$ days to check the effect of storage of purified cellulose on its activity.

\subsection{Statistical Analysis}

All experiments and enzyme assays were performed in triplicates; data was statistically evaluated according to Steel et al. [22]. The means and standard errors of means (Mean \pm S.E) were calculated for each treatment and S.E values have been displayed as Y-error bars in figures.

\section{RESULTS AND DISCUSSIONS}

\subsection{Production of Cellulase}

Trichoderma viride was cultured in fermentation medium containing $2 \% \mathrm{HCl}$ pretreated wheat straw as growth supported substrate and maximum cellulase activity of $398 \pm 2.43 \mathrm{U} / \mathrm{mL}$ obtained after stipulated fermentation time period [16]. Our results are comparable to Ojumu et al. [23] who reported high cellulase activity from 3\% pretreated saw dust, bagasse and corn cob as substrate respectively. Substrate concentration is a dynamic influencing feature that affects the yield and initial hydrolysis rate of cellulose [24]. Several growth factors affect the productivity and growth of micro-organisms particularly substrate particle size is one of the most critical parameter [25]. It has been reported in lit- 
erature that low cost substrates like wheat flour, wheat bran, rice straws and molasses are suitably effective for growth and enzyme production [26,27]. Optimization of various environmental factors causes an increase of enzymatic activities [28].

\subsection{Purification and Dialysis of Cellulase}

The supernatant with cellulase activity of $79600 \mathrm{U} / 200 \mathrm{~mL}$ and specific activity of $45 \mathrm{U} / \mathrm{mg}$ was used as crude enzyme solution and subjected to partial purification by ammonium sulfate precipitation in two fractions of $0 \%$ $50 \%$ and $50 \%$ - $80 \%$. The crude enzyme was precipitated at $80 \%$ saturation with specific activity of $48 \mathrm{U} / \mathrm{mg}$ and 1.07 fold purification. The pellets (precipitate) were dissolved in minimal volume of $0.2 \mathrm{M}$ Tris-HCl buffer $(\mathrm{pH}$ 8) and dialyzed against distal water with 4 equal changes of water after every $6 \mathrm{~h}$ to remove the extra salt. This dialyzed fraction referred to as partially purified cellulase and loaded on to Sephadex-G-100 gel filtration column. By gel filtration the enzyme was purified to 2.33 fold with a yield and specific activity of $2.11 \%$ and $105 \mathrm{U} / \mathrm{mg}$ respectively (Table $\mathbf{1}$ ).

\subsection{SDS-PAGE}

The purified carboxymethyl cellulase was resolved on a SDS-PAGE (5\% stacking and 12\% separating gel) found to be a homogenous monomeric protein as evident by a single band corresponding to $58 \mathrm{kDa}$ on SDS-PAGE relative to the standard molecular weight markers (Figure 1). The cellulase activity bands identified in this strain showed molecular weight $58 \mathrm{kDa}$, further, the purified cellulase contained only one subunit on SDS- polyacrylamide gel electrophoresis which is comparable to those purified from other fungal species Trichoderma viride, M.W. 38 - $58 \mathrm{kDa}$ [29] and Aspergillus sp., M.W. - 31.2 KDa [30]. The results regarding the molecular

Table 1. Purification summary of cellulase produced from Trichoderma viride under optimum fermentation conditions.

\begin{tabular}{|c|c|c|c|c|c|c|c|}
\hline Sr. No. & Purification Steps & $\begin{array}{c}\text { Total Volume } \\
\text { (mL) }\end{array}$ & $\begin{array}{l}\text { Total Enzyme } \\
\text { Activity (IU) }\end{array}$ & $\begin{array}{l}\text { Total Protein } \\
\text { Content (mg) }\end{array}$ & Specific Activity (U/mg) & Purification fold & \% Yield \\
\hline 1 & Crude Enzyme & 200 & 79600 & 1785 & 45 & 1 & 100 \\
\hline 2 & $\begin{array}{c}\left(\mathrm{NH}_{4}\right)_{2} \mathrm{SO}_{4} \\
\text { Precipitation }\end{array}$ & 30 & 9810 & 205 & 48 & 1.07 & 12.32 \\
\hline 3 & Dialysis & 25 & 6625 & 103 & 64 & 1.42 & 8.32 \\
\hline 4 & Sephadex-G-100 & 12 & 1680 & 16 & 105 & 2.33 & 2.11 \\
\hline
\end{tabular}

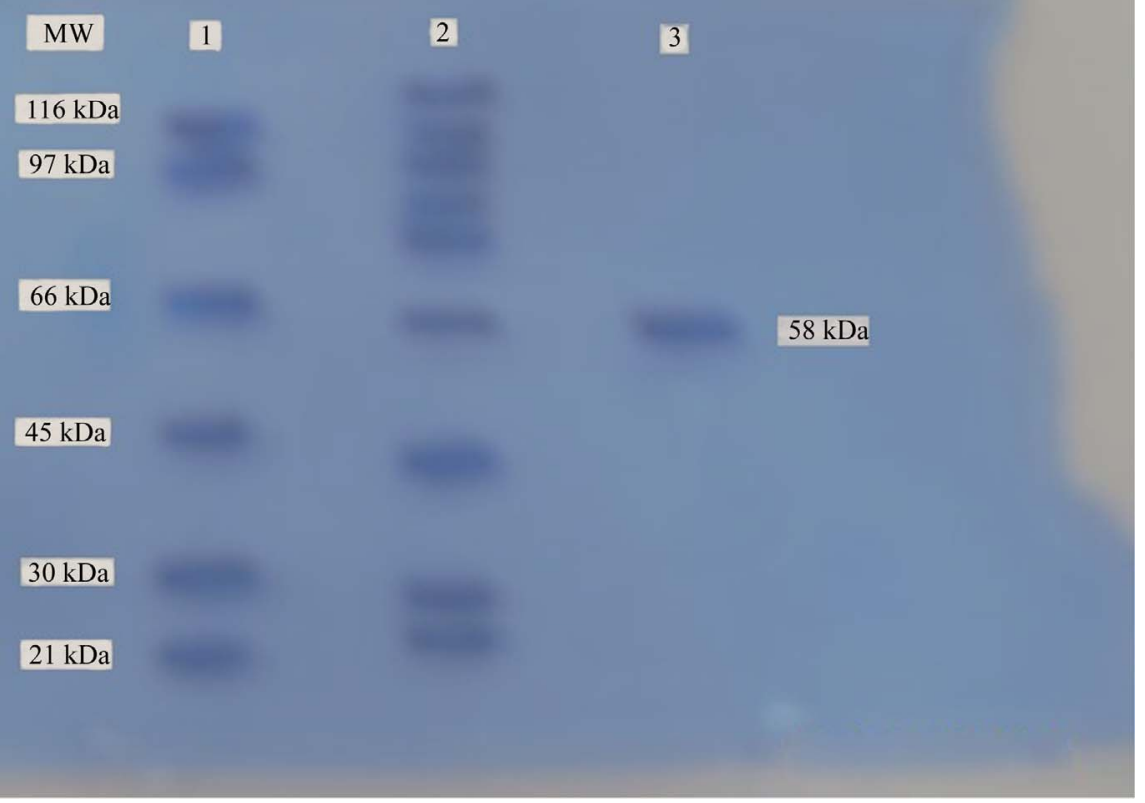

Figure 1. Molecular mass determination of purified cellulase by SDS-PAGE (lane MW, molecular weights in $\mathrm{kDa}$ of standard marker; lane 1 , standard protein markers $(\beta$-Galactosidase, $116 \mathrm{kDa}$; Phosphorylase B, $97 \mathrm{kDa}$; albumin, $66 \mathrm{kDa}$; ovalbumin, $45 \mathrm{kDa}$; carbonic anhydrase, $30 \mathrm{kDa}$ and trypsin inhibitor, $21 \mathrm{kDa}$ ); lane 2, crude cellulase; lane 3, purified cellulase (58 kDa). 
weight of the enzyme are close to the findings of Qin et al. [31] who isolated a CMCase with $54 \mathrm{kDa}$ and our findings show a much intimacy with described figure.

\subsection{Characterization of Purified Cellulase}

\subsubsection{Effect of $\mathrm{pH}$ on Cellulase Activity}

To investigate the effect of different $\mathrm{pH}$ values ranging from 4 - 10 on the purified enzyme, an experiment was conducted with following buffers $(0.2 \mathrm{M})$ : citrate phosphate, $\mathrm{pH}$ 4.0, 5.0 and $\mathrm{pH}$ 6.0; sodium phosphate, $\mathrm{pH} 7.0$ and $\mathrm{pH}$ 8.0; and carbonate buffer, $\mathrm{pH} 9.0$ and $\mathrm{pH} 10.0$. Normal enzyme assay as described earlier was performed after 15 minutes of incubation using carboxymethyl cellulose as substrate on spectrophotometer at the wavelength of $540 \mathrm{~nm}$. Results of enzyme assay showed that the cellulase enzymes was completely active in a large $\mathrm{pH}$ range (5 - 8) and presented an optimum activity of $155 \mathrm{U} / \mathrm{mL}$ at a pH value of 8 (Figure 2) which was little higher than those from Mucor circinelloides, 4.0 7.0 [32] and Bacillus circulans, 4.5 - 7.0 [33]. Where as any further increase in $\mathrm{pH}$ from optimum value $(\mathrm{pH}, 8)$ cellulase showed decreasing trends in its activity. This little variation in $\mathrm{pH}$ optima may be due to the genetic variability among different species.

\subsubsection{Effect of Temperature on Cellulase Activity}

The experiment was conducted to determine the effect of different incubation temperatures $\left(30-60^{\circ} \mathrm{C}\right)$ on the purified enzyme. The purified cellulase was incubated under different temperature controlled conditions. After 15 minutes of incubation cellulase was assayed to determine the effect of temperature on enzyme activity with the same procedure as mentioned previously. Temperature optimum for purified cellulase was observed at $55^{\circ} \mathrm{C}$. Results of Figure 3 showed that at temperatures higher than $55^{\circ} \mathrm{C}$ enzyme starts to losses its activity rapidly as the denaturation of the enzymic protein occurs at elevated temperatures. For a variety of industrial applications relatively high thermostability is an attractive and desirable characteristic of an enzyme [34,35]. Our results are in close agreement with the findings of Thongekkaew et al. [3] who reported $40-50^{\circ} \mathrm{C}$ as an optimum temperate during the characterization of CMCase produced from Cryptococcus sp. S-2 where as, Fadel [34] found $55^{\circ} \mathrm{C}$ as a best temperature at which the enzyme was most active and stable. Saha [36] also reported the same temperature i.e. $55^{\circ} \mathrm{C}$ as optimum for CMCase activity.

\subsubsection{Effect of Substrate Concentration: Determination of $K_{\mathrm{M}}$ and $V_{\max }$}

The Michalis-Menten kinetic constants $K_{\mathrm{M}}$ and $V_{\max }$ for purified cellulase were determined by using varying concentration of carboxymethyl cellulose ranging from
$100-1000 \mu \mathrm{M}$. Enzyme activities were measured under standard assay conditions as described earlier and Enzyme activity $(\mathrm{U} / \mathrm{mL})$ against concentration of substrate $(\mu \mathrm{M})$ was plotted, which yielded a hyperbolic curve, as shown in Figure 4. From the catalytic properties, $K_{\mathrm{M}}$ and $V_{\max }$ values of purified cellulase from Trichoderma viride were $68 \mu \mathrm{M}$ and $148 \mathrm{U} / \mathrm{mL}$ respectively. In literature, different ranges of $K_{\mathrm{M}}$ and $V_{\max }$ for different

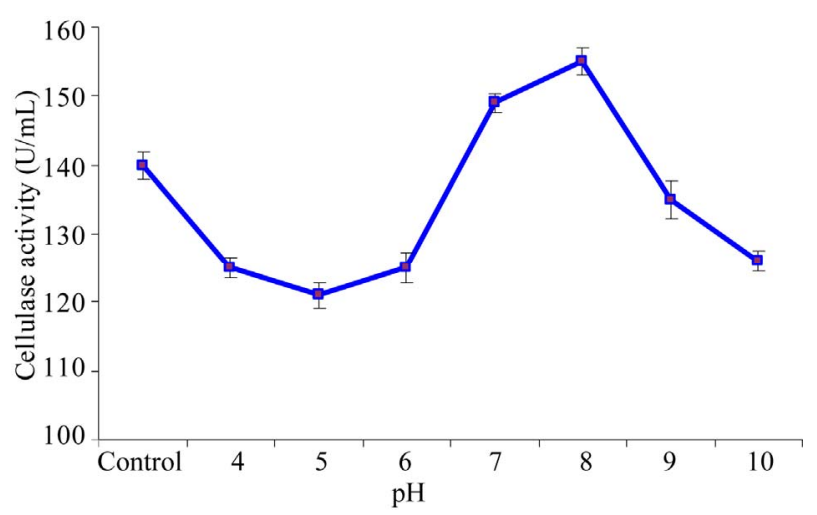

Figure 2. Effect of varying $\mathrm{pH}$ values on purified cellulase activity.

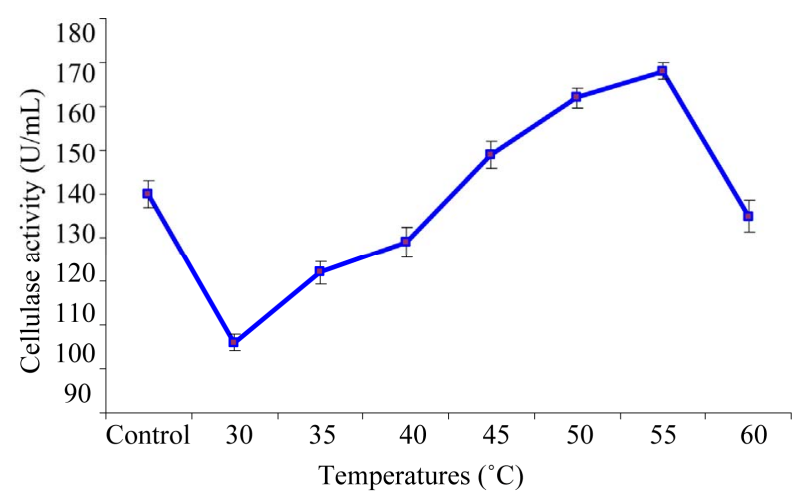

Figure 3. Effect of different temperatures on purified cellulase activity.

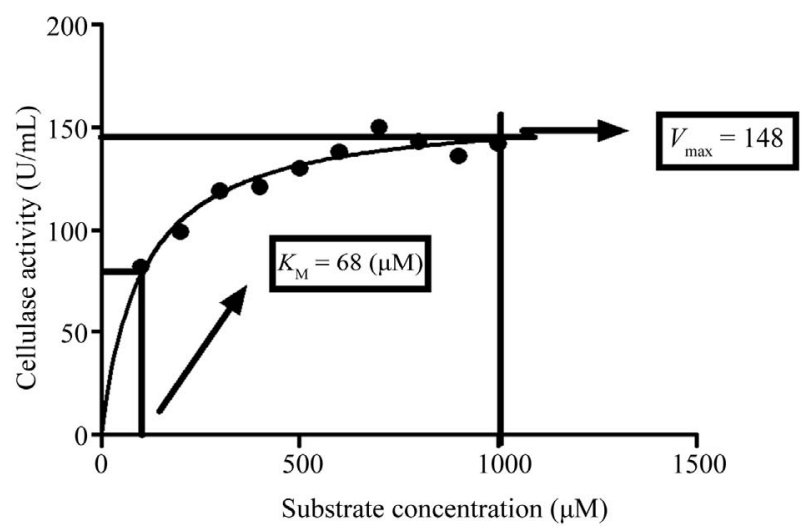

Figure 4. Determination of $K_{\mathrm{M}}$ and $V_{\max }$ for purified cellulase through Michaelis-Menten kinetics. 
fungal species have been reported. According to Ekperigin [37] $K_{\mathrm{M}}$ values for A. anitratus and Branhamella sp. are 0.32 and $2.54 \mathrm{mM}$ for the cellobiose as substrate while for CMC substrate were to be 4.97 and $7.90 \mathrm{mg} / \mathrm{mL}$ for the same species respectively. Similarly, $K_{\mathrm{M}}$ value of $3.6 \mathrm{mg} / \mathrm{mL}$ for Pseudomonas fluorescens and $1.1 \mathrm{mM}$ for Trichoderma reesei reported by Bakare et al. [38] and Cascalheira and Queiroz, [39] respectively. The difference in $K_{\mathrm{M}}$ value of the presently purified cellulase from Trichoderma viride and other reported fungal species may be due to the genetic variability among different species.

\subsubsection{Effect of Activators and Inhibitors}

The purified cellulase extract was incubated along with different activators and inhibitors $(100 \mu \mathrm{L})$ for $15 \mathrm{~min}$ utes at $55^{\circ} \mathrm{C}$ followed by the normal assay protocol. As shown in Figure 5 that among various compounds and metal ions; SDS, EDTA, and $\mathrm{Hg}^{2+}$ showed inhibitory effect on purified cellulase whereas, the enzyme activated by $\mathrm{Co}^{2+}$ and $\mathrm{Mn}^{2+}$ at a concentration of $1 \mathrm{mM}$ as compare to control. Bakare et al. [38] reported an inhibitory effect of EDTA to the activities of cellulase from wild type of Pseudomonas fluorescens. According to Saha, [36] and Lucas et al. [40] $\mathrm{Co}^{2+}$ and $\mathrm{Mn}^{2+}$ activate the enzyme that from Mucor circinelloides and Chalara paradoxa respectively.

\subsection{Industrial Application}

\subsubsection{Detergent Compatibility of Purified Cellulase}

For the possible commercial exploitation of cellulase in detergent industry, the purified cellulase was tested for its compatibility with four different detergents of expected use. The enzyme incubated at $55^{\circ} \mathrm{C}$ with detergent solution revealed maximum compatibility with Surf Excel and followed by Ariel (Figure 6). Therefore, their suitable controls were also run and their activities were found very low as compared to those supplemented with cellulase. This revealed that the cellulase is compatible with local detergents and suggesting its potential as suitable additive to detergents.

\subsubsection{Shelf Life of Purified Cellulase}

The effect of storage of purified cellulase on its activity was determined as it is an important parameter for commercial utilization of enzyme. The enzyme stored at room temperature $\left(30^{\circ} \mathrm{C}\right)$ for up to 30 days (Table 2) revealed that the enzyme was $88 \%$ active for 20 days and the activity is reduced to 75 and $58 \%$ after $25^{\text {th }}$ and $30^{\text {th }}$ day respectively. Storage suggesting that enzyme may be stored for up to 20 days at room temperature without much loss in its activity.

\section{CONCLUSIONS}

The purified cellulase has molecular weight of $58 \mathrm{kDa}$

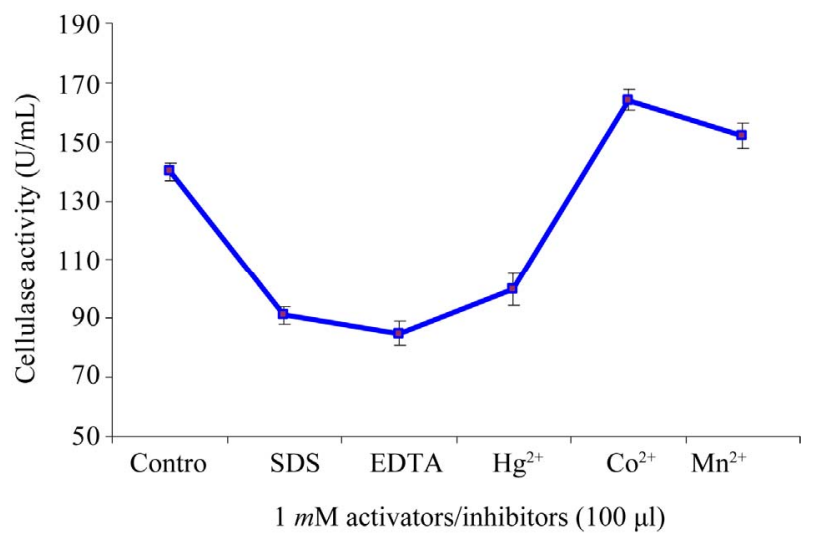

Figure 5. Effect of various activators and inhibitors on purified cellulase activity.

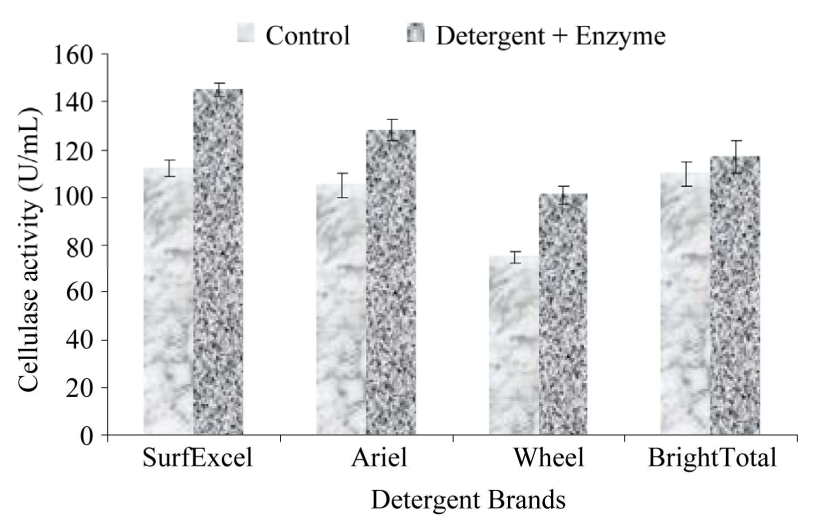

Figure 6. Detergent compatibility of purified cellulase with four local detergent brands.

Table 2. Effect of storage (shelf life) on purified cellulase activity at room temperature*.

\begin{tabular}{cc}
\hline Shelf Life (Days) & Cellulase relative activity (\%) \\
\hline 0 & 100 \\
15 & 93 \\
20 & 88 \\
25 & 75 \\
30 & 58
\end{tabular}

$* 30^{\circ} \mathrm{C}$.

with an optimum activity at $\mathrm{pH} 8$ and $55^{\circ} \mathrm{C}$. The purified enzyme showed maximum activity $\left(V_{\max }\right)$ of $148 \mathrm{U} / \mathrm{mL}$ with its corresponding $K_{\mathrm{M}}$ value of $68 \mu \mathrm{M}$. The specific activity and substrate affinity of this cellulase from Trichoderma viride is greater than those of other reported Trichoderma sp; and also compatible with four local detergent brands with up to 20 days of shelf life at room temperature suggesting its potential as a detergent additive for improved washing therefore, it is concluded that it may be potentially useful for industrial purposes espe- 
cially for detergent and laundry industry.

\section{REFERENCES}

[1] Shallom, D. and Shoham, Y. (2003) Microbial hemicellulases. Current Opinion in Microbiology, 6, 219-228. doi:10.1016/S1369-5274(03)00056-0

[2] Kaur, J., et al. (2007) Purification and characterization of two endoglucanases from Melanocarpus sp. MTCC 3922. Bioresource Technology, 98, 74-81. doi:10.1016/j.biortech.2005.11.019

[3] Thongekkaew, J., et al. (2008) An acidic and thermostable carboxymethyl cellulase from the yeast Cryptococcus sp. S-2: Purification, characterization and improvement of its recombinant enzyme production by high cell-density fermentation of Pichia pastoris. Protein Expression and Purification, 60, 140-146. doi:10.1016/j.pep.2008.03.021

[4] Bhat, M.K. (2000) Cellulases and related enzymes in biotechnology. Biotechnology Advances, 18, 355-383. doi:10.1016/S0734-9750(00)00041-0

[5] Parry, N.J., et al. (2001) Biochemical characterization and mechanism of action of a thermostable ß-glucosidase purified from Thermoascus aurantiacus. Biochemical Journal, 353, 117-127.

[6] Kirk, O., Borchert, T.V. and Fuglsang, C.C. (2002) Industrial enzyme applications. Current Opinion in Biotechnology, 13, 345-351. doi:10.1016/S0958-1669(02)00328-2

[7] Cherry, J.R. and Fidantsef, A.L. (2003) Directed evolution of industrial enzymes: An update. Current Opinion in Biotechnology, 14, 438-443. doi:10.1016/S0958-1669(03)00099-5

[8] Pérez-Guerra, N., et al. (2003) Main characteristics and applications of solid-state fermentation. Electronic Journal of Environmental, Agricultural and Food Chemistry, 2, 343-350.

[9] Viniegra-Gonzáles, G., et al. (2003) Advantages of fungal enzyme production in solid state over liquid fermentation system. Biochemical Engineering Journal, 13, 157-167. doi:10.1016/S1369-703X(02)00128-6

[10] Xia, L. and Cen, P.L. (1999) Cellulase production by solid state fermentation on lignocellulosic waste from the xylose industry. Process Biochemistry, 34, 909-912. doi:10.1016/S0032-9592(99)00015-1

[11] Gao, J., et al. (2008) Production and characterization of cellulolytic enzymes from the thermoacidophilic fungal Aspergillus terreus M11 under solid state cultivation of corn stover. Bioresource Technology, 99, 7623-7629. doi:10.1016/j.biortech.2008.02.005

[12] Latifian, M., Hamidi-Esfahani, Z. and Barzegar, M. (2007) Evaluation of culture conditions for cellulose production by two Trichoderma reesei mutants under solid-state fermentation conditions. Bioresource Technology, 98, 3634-3637. doi:10.1016/j.biortech.2006.11.019

[13] Leite, R.S.R., et al. (2008) Production and characteristics comparison of crude â-glucosidases produced by microorganisms Thermoascus aurantiacus and Aureobasidium pullulans in agriculture wastes. Enzyme and Microbial Technology, 43, 391-395. doi:10.1016/j.enzmictec.2008.07.006

[14] Colombatto, D., Mould, F.L. and Bhat, M.K. (2003) Use of fibrolytic enzymes to improve the nutritive value of ruminant diets. A biochemical and in vitro rumen degradation assessment. Animal Feed Science and Technology, 107, 201-209. doi:10.1016/S0377-8401(03)00126-3

[15] Dhillon, S.S., et al. (2004) Studies on the utilization of citrus peel for pectinase production using fungus Aspergillus niger. International Journal of Environmental Studies, 61, 199-210. doi:10.1080/0020723032000143346

[16] Ahmed, I., Zia, M.A. and Iqbal, H.M.N. (2010) Bioprocessing of proximally analyzed wheat straw for enhanced production of cellulase through parameters optimization with Trichoderma viride under SSF. International Journal of Biological and Life Sciences, 6, 164-170.

[17] Ghose, T.K. (1987) Measurement of cellulase activities. Pure and Applied Chemistry, 59, 257-268. doi:10.1351/pac198759020257

[18] Lowry, O.H., et al. (1951) Protein measurement with folin phenol reagent. The Journal of Biological Chemistry, 193, 265-275.

[19] De-Moraes, L.M.P., Filho, S.A. and Ulhaa, C.J. (1999) Purification and some properties of an alpha amylase and glucoamylase fusion protein from Saccharomyces cerevisiae. World Journal of Microbiology and Biotechnology, 15, 561-564. doi:10.1023/A:1008961015119

[20] Sharma, J., et al. (2006) Partial purification of an alkaline protease from a new strain of Aspergillus oryzae AWT 20 and its enhanced stabilization in entrapped Ca-Alginate beads.

http://www.ispub.com/ostia/index.php?xmlFilePath=jour nals/ijmb/vol2n2/awt.xml

[21] Laemmli, U.K. (1970) Cleavage of structural proteins during assembly of head of bacteriophage T4. Nature, 227, 680-685. doi:10.1038/227680a0

[22] Steel, R., Torrie, J. and Dickey, D. (1997) Principles and procedure of statistics. McGraw Hill Book Co Inc., New York.

[23] Ojumu, T.V., et al. (2003) Cellulase production by $A s$ pergillus flavus linn isolate NSPR 101 fermented in sawdust, bagasse and corncob. African Journal of Biotechnology, 2, 150-152.

[24] Raghavarao, K.S.M.S., Ranganathan, T.V. and Karanth, N.G. (2003) Some engineering aspects of solid state fermentation. Biochemical Engineering Journal, 13, 127135. doi:10.1016/S1369-703X(02)00125-0

[25] Zadrazil, F. and Punia, A.K. (1995) Studies on the effect of particle size on solid state fermentation of sugar cane bagasse into animal feed using white rot fungi. Bioresource Technology, 54, 85-97. doi:10.1016/0960-8524(95)00119-0

[26] Mehta, V.J., Thumar, J.T. and Singh, S.P. (2006) Production of alkaline protease from an alkaliphilic actinomycete. Bioresource Technology, 97, 1650-1654. doi:10.1016/j.biortech.2005.07.023

[27] Sen, S., Veeranki, V.D. and Mandal, B. (2009) Effect of physical parameters, carbon and nitrogen sources on the production of alkaline protease from a newly isolated Bacillus pseudofirmus SVB1. Annals of Microbiology, 59, 531-538. doi:10.1007/BF03175142

[28] Odeniyi, O.A., Onilude, A.A. and Ayodele, M.A. (2009) Production characteristics and properties of cellulase/po- 
lygalacturonase by a Bacillus coagulans strain from a fermenting palm-fruit industrial residue. African Journal of Microbiology Research, 3, 407-417.

[29] Ogawa, K. (1990) Fractionation and purification of cellulases from Trichoderma viride. Bulletin of the Faculty of Agriculture - Miyazaki University, 36, 271-280.

[30] Olama, Z.A., Hamza, M.A., El-Sayed, M.M. and Abdel-Fattah, M. (1993) Purification properties and factors affecting the activity of Trichoderma viride cellulose. Food Chemistry, 47, 221-226. doi:10.1016/0308-8146(93)90153-7

[31] Qin, Y., et al. (2008) Purification and characterization of recombinant endoglucanase of Trichoderma reesei expressed in Saccharomyces cerevisiae with higher glycosylation and stability. Protein Expression and Purification, 58, 162-167. doi:10.1016/j.pep.2007.09.004

[32] Kim, C.H. (1995) Characterization and substrate specificity of an endo-beta-1,4-D-glucanase I (Avicelase I) from an extra cellular multienzyme complex of Bacillus circulans. Applied and Environmental Microbiology, 61, 959-965

[33] Beg, Q.K. and Gupta, R. (2003) Purification and characterization of an oxidation-stable, thiol-dependent serine alkaline protease from Bacillus mojavensis. Enzyme and Microbial Technology, 32, 294-304. doi:10.1016/S0141-0229(02)00293-4

[34] Fadel, M. (2000) Production physiology of cellulases and $\beta$-glucosidase enzymes of Aspergillus niger grown under solid state fermentation conditions. Online Journal of Biological Sciences, 1, 401-411.

[35] Haddar, A., et al. (2009) Two detergent stable alkaline serine-proteases from Bacillus mojavensis A21: Purification, characterization and potential application as a laundry detergent additive. Bioresource Technology, 100, 33663373. doi:10.1016/j.biortech.2009.01.061

[36] Saha, B.C. (2004) Production purification and properties of endoglucanase from a newly isolated strain of Mucor circinelloides. Process Biochemistry, 39, 1871-1876. doi:10.1016/j.procbio.2003.09.013

[37] Ekperigin, M.M. (2007) Preliminary studies of cellulase production by Acinetobacter anitratus and Branhamella sp. African Journal of Biotechnology, 6, 28-33.

[38] Bakare, M.K., et al. (2005) Purification and characterization of cellulase from the wild-type and two improved mutants of Pseudomonas fluorescens. African Journal of Biotechnology, 4, 898-904.

[39] Cascalheira, J.F. and Queiroz, J.A. (1999) Kinetic study of the cellobiase activity of Trichoderma reesei cellulose complex at high substrate concentrations. Biotechnology Letters, 21, 651-655. doi:10.1023/A:1005525015777

[40] Lucas, R., et al. (2001) Production, purification, and properties of an endoglucanase produced by the hyphomycete Chalara (syn. Thielaviopsis) paradoxa CH32. Journal of Agriculture and Food Chemistry, 49, 79-85. doi:10.1021/jf000916p 